\title{
Effect of microbially enriched vermicompost on the growth and biochemical characteristics of okra (Abelmoschus Esculentus (L.) moench)
}

\begin{abstract}
The application of microbially enriched vermicompost has significant effect on the growth of Okra (Abelmoschus esculentus (L.) Moench). The growth characters such as seed germination, seedling vigour index, shoot len gth, root length, plant fresh weight and plant dry weight were significantly higher in plants amended with enriched vermicompost. The effect was varied with nature of microbes used for the enrichment. The response was superior in the enriched vermicompost over the control. Among the enrichments, the growth characters were more responding to Azospirillum enriched vermicompost. The application of enriched vermicompost has positive effect on the biochemical characters of Okra such as total chlorophyll, carotenoid, protein, amino acids, glucose content and NR activity. Biochemical characters such as total chlorophyll, carotenoid, protein, amino acids were higher in Azospirillum brasilense enriched vermicompost where as in case of glucose and NR activity was higher with Pseudomonas fluorescens enrichment.
\end{abstract}

Keywords: vermicompost, microbial enrichment, growth, biochemical
Volume 6 Issue 5 - 2017

\author{
Tensingh Baliah N,' Muthulakshmi $\mathrm{P}^{2}$ \\ 'Assistant Professor, Post Graduate Department of Botany, India \\ ${ }^{2}$ Research Scholar, Post Graduate Department of Botany, India
}

Correspondence: Assistant Professor, Post Graduate Department of Botany, Ayya Nadar Janaki Ammal College, Sivakasi,Tamilnadu, India, Email tens007@rediffmail.com

Received: October 15, 2016 | Published: March 15, 2017

\section{Introduction}

The modern agricultural farming practices, along with irrational use of chemical inputs over the past four decades have resulted in not only loss of natural habitat balance and soil health but have also caused many hazards like soil erosion, decreased groundwater level, soil salinization, pollution due to fertilizers and pesticides, genetic erosion, ill effects on environment, reduced food quality and increased the cost of cultivation, rendering the farmer poorer year by year. ${ }^{1}$ The continuous use of chemical fertilizers resulted in the decline in organic matter content of the agricultural soil leading to depletion of beneficial microorganisms which in turn reduced the soil productivity. The agricultural land is diminishing exorbitantly and there is no scope for further expansion in area. Hence to meet the increasing demand, the crop production has to be increased per unit area of land. Man made fertilizers containing nitrogen, phosphorus and potassium, increased the output of agricultural products. The demand for chemical fertilizers is keep on increasing, widening the gap between the demand and supply such a gap would be difficult to bridge in the wake of the energy crisis. Therefore, the strategy for improving agricultural production should consider supplementing nitrogen and phosphorus through microbial processes. This can be accomplished through the application of organic fertilizers. Organic agriculture is a holistic production management system which promotes and enhances agro-ecosystem health, including biodiversity, biological cycles and soil biological activity. It emphasizes the use of management practices in preference to the use of off-farm inputs, taking into account that regional conditions require locally adapted systems. This is accomplished by using wherever possible, agronomic, biological and mechanical methods, as opposed to using synthetic materials, to fulfill any specific function within the system'. ${ }^{2}$ Organic manures generally improve the soil physical, chemical, biological properties along with conserving the moisture holding capacity of soil and thus resulting in enhanced crop productivity along with maintaining the quality of crop production.
Vermicompost is a mixture of worm castings, undigested organic wastes, microbes, vitamins, enzymes, hormones and antibiotics. It has less soluble salts, neutral $\mathrm{pH}$, greater ion exchange capacity, humic acid content, nitrates, calcium and magnesium. It improves water holding capacity of the soil. It contains plant hormones like auxins and gibberellins and enzymes which believed to stimulate plant growth and discourage plant pathogens. It also enriches the soil with useful microorganisms which add different enzymes like phosphatases and cellulases to the soil. It enhances germination, plant growth and thus over all crop yield. ${ }^{3,4}$ It is rich in NKP and retain the nutrients for long time and while the conventional compost fails to deliver the required amount of macro and micronutrients including the vital NKP to plants in shorter time. Most of the organic manures are very low in nutrient contents, which are not sufficient to meet the nutritional requirement of the crops, especially when inorganic fertilizers are not applied. ${ }^{5}$ Under such circumstances, fortification of organic manures and composts with permitted additives like rock phosphate, beneficial microbial cultures and neem cake is a feasible option for nutrient supplementation in organic food production.

This necessitates the enrichment of manures with beneficial microbial inoculants like free living nitrogen fixers, phosphate solubilizers etc. to improve the nutritional status of the manures. The enrichment manures with rock phosphate and beneficial microbial cultures result not only in improvement of nutritive value but also in higher growth and yield of crops. The microbial enrichment of organic manures will further contribute to the enhancement of phosphate solubilization, nitrogen fixation and increases the plant growth and development. Azospirillum, phosphor solubilizing bacteria, VAM, etc., are the main types of organisms widely recommended for enrichment of organic manures. Thus, enrichment of organic manures like vermicompost, neem cake, compost with these microbes may reflect in better results compared to organic manure alone. The enrichment of the organic manures with beneficial microbial cultures will further contribute to the enhancement of $\mathrm{N}$ and $\mathrm{P}$ contents through nitrogen 
fixation and phosphate solubilization. Hence, combination of organic and microbial inoculants provides an ideal nutrition strategy for the crop plants. With a view to identify a better nutrient management technique that is economical as well as ecologically efficient.

\section{Materials and methods}

Microbial enrichment of vermicompost For the enrichment of vermicompost, the various microbial inoculants were mixed individually under lab condition. The moisture content was optimally maintained for facilitative growth of mixed inoculants. The enriched vermicompost were kept for 21days for maximal changes such as physical, chemical and biological activities. After the enrichment, the enriched vermicompost were used for the nursery experiment.

Nursery experiment A nursery experiment was conducted to study the nursery performance of microbially enriched vermicompost. The soil mixture was prepared by mixing of black soil, red soil and sand in the ratio of 1:1:1 for the nursery experiment. The microbially enriched vermicomposts were applied $10 \mathrm{~g}$ each at the top soil of the pots at regular interval for 30 days. The experimental details were

i. Control,

ii. Vermicompost,

iii. Vermicompost + Pseudomonas fluorescens,

iv. Vermicompost + Azospirillum brasilense and

v. Vermicompost + Bacillus megaterium .

The growth parameters such as seed germination, ${ }^{6}$ germination index, ${ }^{7}$ seedling vigour index I (SVI I) and II (SVI II), ${ }^{8}$ shoot length, root length, number of leaves, fresh weight and dry weight were studied in the treated and untreated control plants. The number of seeds germinated in each treatment was counted on 7 day after sowing. The final count of germination was recorded on the $7^{\text {th }}$ day and number of normal seedlings was expressed as percentage germination. Germination Index was calculated with the number of germinated seeds and days of first count to the days of last count. Seedling Vigour Index was calculated with the help of data recorded on germination percentage and seedling growth. Seedling Vigour Index II was calculated with the help of data recorded on germination percentage and seedling dry weight. For the analysis of plant biomass, the plants were uprooted without causing any damage to the seedlings and it was thoroughly washed with tap water in order to remove soil and debris particle. Then the shoot length was measured with the help of meter scale. In uprooted plants, the root length was measured with the help of meter scale and expressed in centimeter. The fresh weight of whole plant parts (shoot, leaves and root) was weighed using electronic balance. The fresh undamaged whole plant system of seedlings were kept in the oven at $80^{\circ} \mathrm{C} 4-6$ hours and the dried seedlings were weighed using electronic balance. Biochemical characters such as Chlorophyll and carotenoids, ${ }^{9}$ Protein, ${ }^{10}$ total glucose,,${ }^{11}$ free amino acid, ${ }^{11}$ NR activity ${ }^{12}$ and ascorbic acid ${ }^{13}$ were estimated.

Statistical Analysis The data obtained were subjected to analysis of variance (ANOVA) and the significant means were segregated by critical difference $(\mathrm{CD})$ at $0.05 \%(\mathrm{CD} \mathrm{P}=0.05 \%)$ level of significance.

\section{Results}

The effect of microbially enriched vermicompost on the growth and biochemical characteristics of Okra (Abelmoschus esculentus
(L.) Moench) was analyzed in the nursery experiment. The growth characters such as germination percentage, germination index, seedling vigour index, shoot length, root length, number of leaves, fresh weight and dry weight were analyzed in the microbially enriched vermicompost treated and untreated control. The results revealed that there was a significant difference was observed in the rate of seed germination of Okra and the rate was higher in the plants treatment with vermicompost enriched with Pseudomonas fluorescens, Azospirillum brasilense and Bacillus megaterium over the control. Among them, A. brasilense enrichment is superior to others. The speed of germination index also varied according to nature of enrichment of vermicompost. Little difference was shown in germination index among different microbial enrichment. But the effect was significantly higher than control. The values of the vigour index of the okra also varied according to the nature of enrichment. The lowest of vigour index was shown by the control plant and the highest value of vigour index was for the application of soil to vermicompost with $A$. brasilense followed by $B$. megaterium and $\mathrm{P}$. fluorescens. The trend was similar in both in SVI- I and SVI- II (Table $1)$. With reference to the plant biomass production, A. brasilense, $B$. megaterium, P. fluorescens enriched vermicompost improved the shoot length compared to control. Among them, A. brasilense enriched vermicompost respond well followed by enriched with $B$. megaterium. The application of vermicompost in combination with microbial inoculants highly influenced the root length of Okra plants. Plants amended with vermicompost with PGPR (P. fluorescens) responded better than if grown in other microbial enrichment and vermicompost alone. Further, the number of leaves per plant was significantly influenced by microbially enriched vermicompost than vermicompost alone. The highest number of leaves was found in plants enriched with $A$. brasilense closely followed by $B$. megaterium. The fresh and dry weight of the T4 (vermi compost and A. brasilense) was found to be maximum, which was followed by T5 (vermi compost and B. megaterium), T3 (vermi compost and P. fluorescens) and T2 (vermi compost alone) (Table 2).

In the nursery plants, the biochemical characters such as total chlorophyll, carotenoid, glucose, protein, free aminoacids, NR activity and ascorbic acid were estimated to found out the beneficial effect of microbes enriched organic manure with reference to biochemical response in the okra plants. The total chlorophyll content was found to be maximum in the $\mathrm{T} 4$ (vermicompost + A. brasilense) when compared to the other treated plants. The effect was comparatively higher in the microbial enrichment than the non enriched vermicompost and control plants. The microbial enriched treatments were increased the leaf carotenoid in okra plants than control plants. But, there was not significant differences found among the treatments (Table 3 ). The glucose content of okra was highly enhanced by the application of enriched vermicompost with $B$. megaterium than other enrichments and non-enriched vermicompost. The protein content of all the treatments was found to be significantly higher when compared to the control. Among the treatments, the vermicompost enriched with $A$. brasilense recorded the highest protein content followed by $B$. megaterium enriched vermicompost. The aminoacid content level was higher in the plants treated with $A$. brasilense enriched vermicompost which was followed by enrichment with B. megaterium (Table 4).

All the treatments recorded maximum activity of nitrate reductase when compared to the control plants. Among the treatments, T5 (vermicompost with $B$. megaterium) was found to be superior in registering the maximum activity of nitrate reductase. NR activity was 
comparatively lower in plants with vermicompost alone and control plants. Ascorbic acid is very common and significant in the Okra fruits. Ascorbic acid content was estimated in the fruit of Okra. The results revealed that the application of vermicompost enriched with $\mathrm{A}$. brasilense recorded the maximum ascorbic acid content followed $B$. megaterium and P. fluorescens enrichment.

Table I Effect of microbially enriched vermicompost on the growth characters of okra

\begin{tabular}{|c|c|c|c|c|c|}
\hline $\begin{array}{l}\text { S. } \\
\text { No. }\end{array}$ & Treatment & $\begin{array}{l}\text { Seed germination } \\
(\%)\end{array}$ & $\begin{array}{l}\text { Germination } \\
\text { index }\end{array}$ & Seedling vigour index I & $\begin{array}{l}\text { Seedling Vigour } \\
\text { index II }\end{array}$ \\
\hline I & Control & 76 & 0.6 & $14.22 \mathrm{e} \pm 0.14100$ & $0.39 \mathrm{~d} \pm 0.0 \mathrm{I}-100$ \\
\hline 2 & Vermicompost & 80 & 0.93 & $18.24 d \pm 0.20128$ & $0.54 c \pm 0.04-138$ \\
\hline 3 & $\begin{array}{l}\text { Vermicompost+P. } \\
\text { fluorescens }\end{array}$ & 88 & 1.33 & $21.31 b \pm 0.14149$ & $0.67 c \pm 0.03-172$ \\
\hline 4 & $\begin{array}{l}\text { Vermicompost }+\mathrm{A} \text {. } \\
\text { brasilense }\end{array}$ & 96 & 1.46 & $26.8 \mathrm{a} \pm 0.20=113$ & $1.03 a \pm 0.02-264$ \\
\hline 5 & $\begin{array}{l}\text { Vermicompost+B. } \\
\text { megaterium }\end{array}$ & 91 & 1.4 & $23.23 c \pm 0.15163$ & $0.84 b \pm 0.03-215$ \\
\hline \multicolumn{2}{|c|}{$C D P=0.05 \%$} & & & 1.112 & 0.1432 \\
\hline
\end{tabular}

Table 2 Effect of microbially enriched vermicompost on the growth characters of okra

\begin{tabular}{|c|c|c|c|c|c|c|}
\hline $\begin{array}{l}\text { S. } \\
\text { No. }\end{array}$ & Treatment & $\begin{array}{l}\text { Shoot } \\
\text { length(Cm) }\end{array}$ & $\begin{array}{l}\text { Root } \\
\text { length(Cm) }\end{array}$ & $\begin{array}{l}\text { Number of leaves/ } \\
\text { Plant }\end{array}$ & $\begin{array}{l}\text { Fresh } \\
\text { weight(G) }\end{array}$ & Dry Wt(G) \\
\hline I & Control & $25.4 \mathrm{~d} \pm 0.14-100$ & $17.6 \mathrm{e} \pm 0.17-100$ & $12 \mathrm{e} \pm 0.57-100$ & $\begin{array}{l}2.19 e \pm 0.03- \\
100\end{array}$ & $\begin{array}{l}0.59 \mathrm{e} \pm 0.07- \\
100\end{array}$ \\
\hline 2 & Vermicompost & $28.5 e \pm 0.23-112$ & $20.4 d \pm 0.15-115$ & $|7 d \pm 0.33-| 4 \mid$ & $\begin{array}{l}3.35 \mathrm{~d} \pm 0.05- \\
152\end{array}$ & $\begin{array}{l}0.85 d \pm 0.11- \\
144\end{array}$ \\
\hline 3 & $\begin{array}{l}\text { Vermicompost+P. } \\
\text { fluorescens }\end{array}$ & $29.6 c \pm 0.14-116$ & $24.5 b \pm 0.12-139$ & $25 c \pm 0.33-208$ & $3.9 \mid c \pm 0.02-178$ & $\begin{array}{l}0.93 c \pm 0.13- \\
157\end{array}$ \\
\hline 4 & $\begin{array}{l}\text { Vermicompost+A. } \\
\text { brasilense }\end{array}$ & $33.5 a \pm 0.20-132$ & $\begin{array}{l}22.6 c \pm 0.24- \\
128\end{array}$ & $30 \mathrm{a} \pm 0.57-250$ & $4.4 \mathrm{I} a \pm 0.02-20 \mathrm{I}$ & $\begin{array}{l}1.29 a \pm 0.17- \\
218\end{array}$ \\
\hline 5 & $\begin{array}{l}\text { Vermicompost+B. } \\
\text { megaterium }\end{array}$ & $\begin{array}{l}30.56 b \pm 0.18- \\
120\end{array}$ & $21.5 \mathrm{a} \pm 0.17-122$ & $27 b \pm 0.57-250$ & $\begin{array}{l}4.12 b \pm 0.06- \\
188\end{array}$ & $\begin{array}{l}I . I|b \pm 0.2|- \\
I 88\end{array}$ \\
\hline \multicolumn{2}{|c|}{$C D P=0.05 \%$} & 0.7985 & 0.9604 & 0.2077 & 0.4266 & 0.0549 \\
\hline
\end{tabular}

Table 3 Effect of microbially enriched vermicompost on the biochemical characters of okra

\begin{tabular}{|c|c|c|c|c|c|}
\hline $\begin{array}{l}\text { S. } \\
\text { No. }\end{array}$ & Treatment & $\begin{array}{l}\text { Totalchlorophyll (mg/g } \\
\text { LFW) }\end{array}$ & $\begin{array}{l}\text { Carotenoid (mg/g } \\
\text { LFW) }\end{array}$ & $\begin{array}{l}\text { Protein (mg/g } \\
\text { LFW) }\end{array}$ & $\begin{array}{l}\text { Aminoacids (mg/g } \\
\text { LFW) }\end{array}$ \\
\hline I & Control & $2.23 \mathrm{e} \pm 0.16-100$ & $1.44 d \pm 0.15-100$ & $7.66 \mathrm{e} \pm 0.17-100$ & $6.96 \mathrm{e} \pm 0.19-100$ \\
\hline 2 & Vermicompost & $3.11 d \pm 0.12-139$ & $1.95 c \pm 0.17-135$ & $9.81 \mathrm{~d} \pm 0.14-128$ & $8.12 \mathrm{~d} \pm 0.23-119$ \\
\hline 3 & $\begin{array}{l}\text { Vermicompost+P. } \\
\text { fluorescens }\end{array}$ & $3.73 c \pm 0.13-167$ & $2.13 b \pm 0.13-147$ & $10.93 c \pm 0.24-142$ & $9.45 c \pm 0.20-|4|$ \\
\hline 4 & $\begin{array}{l}\text { Vermicompost+A. } \\
\text { brasilense }\end{array}$ & $4.86 a \pm 0.23-217$ & $2.46 a \pm 0.12-170$ & $15.28 a \pm 0.21-199$ & $|2.6| a \pm 0.12-|6|$ \\
\hline 5 & $\begin{array}{l}\text { Vermicompost+B. } \\
\text { megaterium }\end{array}$ & $4.35 b \pm 0.12-195$ & $2.33 a \pm 0.21-|6|$ & $12.32 \mathrm{~b} \pm 0.18-160$ & $10.53 b \pm 0.22-193$ \\
\hline \multicolumn{2}{|c|}{$C D P=0.05 \%$} & 0.0829 & 0.1515 & 0.4198 & 0.2557 \\
\hline
\end{tabular}


Table 4 Effect of microbially enriched vermicompost on the biochemical characters of okra

\begin{tabular}{lllll}
\hline S. No. & Treatment & Glucose $(\mathbf{m g} / \mathbf{g}$ LFW $)$ & NRA $(\boldsymbol{\mu}$ mole/g LFW $)$ & Ascorbic acid $(\mathbf{m g} / \mathbf{~ m l})$ \\
\hline $\mathrm{I}$ & Control & $20.6 \mathrm{~d} \pm 0.13-100$ & $6.08 \mathrm{e} \pm 0.17-100$ & $0.23 \mathrm{~b} \pm 0.11-100$ \\
2 & Vermicompost & $26.4 \mathrm{c} \pm 0.24-128$ & $8.75 \mathrm{~d} \pm 0.15-144$ & $0.3 \mathrm{lb} \pm 0.15-134$ \\
3 & Vermicompost+P. fluorescens & $30.8 \mathrm{~b} \pm 0.23-149$ & $9.66 \mathrm{c} \pm 0.10-159$ & $0.42 \mathrm{a} \pm 0.26-182$ \\
4 & Vermicompost+A. brasilense & $32.8 \mathrm{~b} \pm 0.17-159$ & $10.4 \mathrm{lb} \pm 0.09-17 \mathrm{I}$ & $0.48 \mathrm{a} \pm 0.21-208$ \\
5 & Vermicompost+B. megaterium & $36.6 \mathrm{a} \pm 0.15-177$ & $11.58 \mathrm{a} \pm 0.08-190$ & $0.45 \mathrm{a} \pm 0.19-195$ \\
$\mathrm{CDP}=0.05 \%$ & 1.6427 & 0.2305 & 0.0799
\end{tabular}

\section{Discussion}

The nursery soil amended with enriched vermicompost with microbes/microbial inoculants such as Azospirillum brasilense, Bacillus megaterium and Pseudomonas fluorescens had a positive effect on the crop response, soil biological activity and soil nutrient status. The results indicated that the enriched vermicompost significantly increased crop response of Okra with reference to growth attributes and biochemical attributes. Further, the microbial enriched vermicompost significantly improved the nutrient Status In The Amended Soil.

Growth attributes The application of enriched vermicompost significant increased growth of Abelmoschus esculentus (L.) Moench with reference to seed germination, seedling vigour index, shoot length, root length, plant fresh weight and plant dry weight. The effect was varied with nature microorganisms used for the enrichment. The combined use of vermicompost and biofertilizers significantly increased the vine length in cucumber. The better efficiency in combination with organic manures and biofertilizers might be due to the fact that organic manures would have provided the micronutrients such as zinc, iron, copper, manganese, etc., in an optimum level. Zinc is involved in the biochemical synthesis of the most important plant hormone, Indole Acetic Acid (IAA) through the pathway of conversion of tryptophan to IAA. Iron is involved in the chlorophyll synthesis path way. Application of organic manure would have helped in the plant metabolic activity through the supply of such important micronutrients in the early crop growth phase, which in turn encouraged early vigorous growth. ${ }^{14,15}$ The pot culture studies have shown that the root and shoot parameters all higher in pots supplied with biofertilizer enriched vermicompost this might due to uptake of readily available micro and macro nutrients in the vermicompost and its associated microbes. The combined application of vermicompost, Azospirillum and chemical fertilizer is superior in enhancing the growth and development of the green leafy vegetable, Amaranthus. Thus the increased growth and nutrient content of the Amaranthus plants was proved by the application of biofertilizers along with chemical fertilizers and vermicompost. Hence it is recommended that the use of biofertilizer and vermicompost along with the chemical fertilizer would be beneficial to the environment as it would reduce the use of inorganic fertilizers and promote sustainable agriculture. ${ }^{16}$

Plant growth promoting rhizobacteria when applied to seeds/ soil or crops; enhance the growth of the plant directly by providing nutrients to plants. The improvement in seed germination by PGPR was also found in work with wheat and sunflower, ${ }^{17}$ where it was found that some PGPR induced increases in the seed emergence, in some cases achieving increases up to $100 \%$ greater than controls. The mechanisms by which PGPR promote plant growth are ability to produce or change the concentration of plant hormones: ${ }^{18}$ asymbiotic $\mathrm{N}_{2}$ fixation; ${ }^{19}$ and solubilization of mineral phosphate and other nutrients. ${ }^{20,21}$ Phytohormones are the chemical messengers that play crucial role in the natural growth and occur in low concentration. These phytohormones shape the plant, also affecting seed growth, time of flowering, sex of flowers, senescence of leaves, and fruits. ${ }^{22}$ Biofertilizers have a natural mechanism to supply nutrients to plants by solubilizing phosphorus, nitrogen fixation and by synthesis of plant growth promoting substances. There are microbes present in biofertilizers that increase the soil natural nutrient cycle and help in building soil organic matter and maintain the soil fertility. Bacteria are able to promote growth by acting as biofertlizers. The main advantage of using biofertilizer is being cheaper and safer fertilizers. ${ }^{23}$ Plant growth-promoting rhizobacteria (PGPR) have been widely known to benefit plants through several direct and indirect mechanisms namely biological nitrogen fixation, phosphate and potassium solubilization, production of plant growth regulators, siderophores, hydrolyzing enzymes etc. ${ }^{24,25}$

Biochemical Attributes The soil amendment with different types of microbes enriched vermicompost significantly respond to the biochemical attributes such as total chlorophyll, carotenoid, protein, glucose content, amino acid content and NR activity of Okra. The maximum chlorophyll a, chlorophyll $\mathrm{b}$ and total chlorophyll, carbohydrate and protein content found in plants treated with biofertilizers enriched vermicompost in Vigna unguiculata (L.). Increased amount of chlorophyll contents seems to correlate the increased photosynthetic properties. ${ }^{26-28}$ The application of vermicompost highly enhanced the carbohydrate content in tomato plants. $^{29}$ The combined application of biofertilizer, inorganic fertilizers and vermicompost increased the biochemical constituents in chilli fruits. The biofertilizers added to soil provides macronutrients and micronutrients, which are assimilated by plants and utilized for various metabolic activities to synthesize chlorophyll, required for their normal growth and developments. Various micronutrients are needed for catalytic activities of enzymes essential for respiration, photosynthesis, flowering, fruit setting and seed filing as well as fight against abiotic and biotic stresses..$^{30,31}$

The grain protein content was increased with nitrogen for organic and inorganic sources. ${ }^{32}$ Application of organic manures not only influenced the growth and yield of wheat, but it also helped in enhancing the seed quality parameters. The increase in quality parameters might be due to the higher protein content and better sized seeds with these treatments. Significantly higher protein content in seed was observed in treatment receiving vermicompost with poultry manure in groundnut. ${ }^{33}$ The highest protein content in Okra fruit was recorded with application of $\mathrm{N}$ through FYM, vermicompost, poultry manure and urea over control. ${ }^{34}$ Inoculation with nitrogen fixing 
bacteria always increased leaf NRA suggesting a greater supply of $\mathrm{NO}_{3}$ to the plants over uninoculated control. The increased $\mathrm{NO}_{3}$ uptake may relate to increased root development in response to production of hormones. ${ }^{35,36}$ The wheat plants inoculated with Azospirillum showed greater activity of the nitrate reductase enzyme. ${ }^{9}$

\section{Conclusions}

The present investigation revealed that the plant growth and yield is increased in the plants treated with microbially enriched vermicompost than vermicompost alone. Further, the response also reflected in the microbial dynamics as well as nutrient status of amended soil. The positive effect is differed with reference to microbial enrichment. Among them, the enrichment with Azospirillum brasilense is superior to Bacillus megaterium and Pseudomonas fluorescens. Hence, microbial enrichment of vermicompost is best suit for Okra plant especially Azospirillum enrichment. From this study, it can be concluded that enriched vermicompost would be conducive for greater plant growth and also would improve the soil health and soil fertility status. It can be recommended that by using enriched vermicompost, the yield of Okra can be improved.

\section{Acknowledgements}

None.

\section{Conflict of interest}

The author declares no conflict of interest.

\section{References}

1. Ram M, Mohammadreza D, Sharma SN. Organic farming of rice (Oryza sativa $\mathrm{L}$ )-wheat (Triticum aestivum $\mathrm{L}$ ) cropping system:a review. Int $J$ Agron Plant Prod. 2011;2(3):114-134.

2. FAO. Organic Agriculture, Food and Agriculture Organization of the United Nations Rome. Italy; 1999.

3. Gajalaksmi S, Aabbasi KA. Earthworms and Vermicomposting. Indian J Biotechnol. 2004;3:486-494.

4. Yuda $\mathrm{CH}$, Arry YN, Hariyania P. Biophysical monitoring on the effect on different composition of goat and cow manure on the growth response of maize to support sustainability. Agric Agricul Sci Procedia. 2016;9:118-127.

5. Manna MC, Ghosh PK, Ghosh BN, et al. Comparative effectiveness of phosphate-enriched compost and single superphosphate on yield, uptake of nutrients and soil quality under soybean-wheat rotation. J Agril Sci. 2001;137(1):45-54.

6. ISTA. International Seed Testing Association. International rules for seed testing. Rules 1995 Seed Sci Technol. 1995;13:322-326.

7. AOSA. Association of Official Seed Analyst. Seed Vigour Testing Handbook East Lansing, USA; 1983. 88 p.

8. Kharb RPS, Lather BPS, Deswal DP. Prediction of field emergence through heritability and genetic advance of vigour parameters. Seed $\mathrm{Sci}$ Technol. 1994;22(3):461-466.

9. Zaller JG. Foliar spraying of vermicompost extracts:effects on fruit quality and indications of late-blight suppression of field-grown tomatoes. Biol Agric Hort. 2006;24(2):165-180.

10. Lowry OH, Rosebrough NJ, Farr AL, et al. Protein measurement with Folin phenol reagent. J Bio Chem. 1951;193(1):265-275.

11. Jayaraman J. Laboratory manual in Biochemistry. India: Willey-Estern Co Ltd Madras; 1981. p. 1-65.
12. Jaworski EG. Nitrate Reductase assay in intact plant tissues. Biochem Biophy Res Commun. 1971;43(6):1274-1279.

13. Roe JH. Chemical determination of ascorbic, dehydroascorbis and diketogluconic acids. Met Biochem Anal. 1954;1:115-139.

14. Anburani A, Manivannan K. Effect of integrated nutrient management on growth in brinjal. South Indian Hort. 2002;50(46):377-386.

15. Yuda CH, Arry YN, Hariyania P. Biophysical monitoring on the effect on different composition of goat and cow manure on the growth response of maize to support sustainability. Agric Agricul Sci Procedia. 2016;9:118-127.

16. Achsah RS, Lakshmi Prabha M. Potential of vermicompost produced from Banana waste (Mussa paradisiaca) on the growth parameters of Solanum lycopersicum. Int J Chem Tech Res. 2013;5(5):2141-2153.

17. Shaukat K, Affrasayab S, Hasnain S. Growth responses of Helianthus annus to plant growth promoting rhizobacteria used as a biofertilizer. $J$ Agric Res. 2006;1(6):573-581.

18. Mordukhova EA, Skvortsova NP, Kochetkov VV, et al. Synthesis of the phytohormone indole-3-acetic acid by rhizosphere bacteria of the genus Pseudomonas. Microbiologiya. 1991;60:494-500.

19. Boddey RM, Dobereiner J. Nitrogen fixation associated with grasses and cereals:Recent progress and perspectives for the future. Fert Res. 1995;42(1):241-250.

20. De-Freitas JR, Banerjee MR, Germida JJ. Phosphate-solubilizing rhizobacteria enhance the growth and yield but not phosphorous uptake of canola (Brassica napusL). Biol Fertil Soil. 1997;24(4):358-364.

21. Thakker JN, Goswami D, Vaghela H, et al. Plant growth promoting potentials of Pseudomonas spp. strain OG isolated from marine water. $J$ Plant Interact. 2013;8(4):281-290.

22. Glick BR, Cheng Z, Czarny J, et al. Promotion of plant growth by ACC deaminase-producing soil bacteria. Eur J Plant Pathol. 2007;119(3):329-339.

23. Vessey JK. Plant growth promoting rhizobacteria as biofertilizers. Plant Soil. 2003;255(2):571-586.

24. Chen YP, Rekha PD, Arun AB, et al. Phosphate solubilizing bacteria from subtropical soil and their tricalcium phosphate solubilizing abilities. Appl Soil Ecol. 2006;34(1):33-41.

25. Sangeeth KP, Bhai RS, Srinivasan V. Paenibacillus glucanolyticus, a promising potassium solubilizing bacterium isolated from black pepper ( $P$ iper nigrumL) rhizosphere. J Spic Aromat Crops. 2012;21(2):118-124.

26. Khomami AM, Moharam MG. Plant growth promoting rhizobacteria as biofertilizers. Plant Soil. 2013;3(4):207-265.

27. Hellal FA, Mahfouz SA, Hassan FAS. Partial substitution of mineral nitrogen fertilizer by biofertilizer on (Anethum graveolens L) plant. Agric Biol J North America. 2011;2(4):652-660.

28. Latrach L, Farissi M, Mouradi M, et al. Growth and nodulation of Alfalfa-rhizobia symbiosis under salinity:electrolyte leakage, stomatal conductance, and chlorophyll fluorescence. Turk J Agric For. 2014;38:320 326.

29. Densilin DM, Srinivasan S, Manju P, et al. Effect of individual and combined application of biofertilizers, inorganic fertilizer and vermicompost on the biochemical constituents of Chilli (NS-1701). J Biofertil Biopestici. 2010;2:1

30. Siavoshi M, Laware SL. Organic Fertilizers Role on Antioxidant Enzymes in Rice (Oryza sativa L). Int J Farm Alli Sci. 2013;2(S2):13371342 .

31. Berova M, Karanatsidis G. Physiological response and yield of pepper plants (Capsicum annum L) to organic fertilization. J Central Eur Agric. 2008;9(4):715-722. 
32. Nanjundappa G, Shivaraj B, Janarjuna S, et al. Effect of organic and inorganic sources of nutrients applied alone or in combination on growth and yield of sunflower (Helianthus annuus L). Dept Agron Univ Agric Sci Bangalore India. 2001;24(34):115-119.

33. Kachot NA, Malavia DD, Solanki RM, et al. Intedrated nutrient management in rainy-season groundnut (Arachis hypogaea L ). Indian J Agron. 2001;46(3):516-522.

34. Yadav SK, Dhankar BS, Deshwal DP, et al. Effect of sowing date and plant geometry on seed production and quality of okra (Abelmoschus esculenthus (L) Moench.) cv. Varsha Uphar Seed Res. 2001;29(2):149152.
35. Tilak KVBR, Subba Rao. Association of Azospirillum brasilense with pearl millet. Biol Fert Soil. 1987;4(1):97-102.

36. Ferreira ME, Cruz MCP, Da Cruz MCP. Effect of compost from municipal wastes digested by earthworms on the dry matter production of maize and on soil properties. Cientifica Jaboticabal. 1992;20:217-226. 